\title{
Every Great Revolution Is a Civil War
}

\section{Citation}

Armitage, David. 2015. Every Great Revolution Is a Civil War. In Scripting Revolution: A Historical Approach to the Comparative Study of Revolutions, eds. Keith Michael Baker and Dan Edelstein. Stanford University Press: 57-68, 269-71.

\section{Published Version}

http://www.sup.org/books/title/?id=24689

\section{Permanent link}

http://nrs.harvard.edu/urn-3:HUL.InstRepos:29425101

\section{Terms of Use}

This article was downloaded from Harvard University's DASH repository, and is made available under the terms and conditions applicable to Open Access Policy Articles, as set forth at http:// nrs.harvard.edu/urn-3:HUL.InstRepos:dash.current.terms-of-use\#OAP

\section{Share Your Story}

The Harvard community has made this article openly available.

Please share how this access benefits you. Submit a story.

Accessibility 


\title{
Every Great Revolution is a Civil War
}

\author{
DAVID ARMITAGE
}

Originality and novelty define the modern script of revolution. That script was original in the sense that it had identifiable beginnings that have been precisely located in France in 1789 when "revolution was revolutionised". And it was novel because in that year "the French imagined a radical break with the past achieved by the conscious will of human actors, an inaugural moment for a drama of change and transformation projected indefinitely into the future." After 1789 , revolution in the singular replaced revolutions in the plural. What had been understood before 1789 as unavoidable features of nature, as predetermined astronomical cycles, or as eternal recurrences in human affairs became instead voluntary, transformative, and repeatable: revolution as fact gave way to revolution as act. With that daring feat of collective imagination, revolution became ineluctably political, covering primarily but not exclusively fundamental changes concerned with the distribution of power and sovereignty. In the years after 1789 , revolution also developed into an authority in its own right, in whose name political violence could be legitimated. Taken together, these features made up "the script for modern politics invented in 1789 ". ${ }^{1}$

\footnotetext{
${ }^{1}$ Keith Michael Baker, "Revolution 1.0”, Journal of Modern European History 11 (2013), 189; Baker, "Inventing the French Revolution", in Baker, Inventing the French Revolution (Cambridge, 1990), 203, 223; Dan Edelstein, "Do We Want a Revolution without Revolution? Reflections on Political Authority", French Historical Studies 35 (2012), 269-89; compare Alain Rey, “Révolution”. Histoire d'un mot (Paris, 1989); William H. Sewell, Jr., "Historical Events as Transformations of Structures: Inventing Revolution at the Bastille", in Sewell, Logics of History: Social Theory and Social Transformation (Chicago, 2005), $225-$ 70.
} 
These elements comprised the originary conception of revolution as a process by which the world could be made over again. "[E]very revolution", noted François Furet, "and above all the French Revolution itself, has tended to perceive itself as an absolute beginning, as ground zero of history": paradoxically, the uniqueness of each successive revolution became an index of its universality. ${ }^{2}$ The modern script of revolution may have been new in 1789 but it has been frequently replayed on stages around the world. The authors of later revolutions adapted it to their purposes and added new properties for each performance. Their revolutionary dramas borrowed lines and gestures, symbols and costumes, from previous productions. Such borrowings could constrain the actors, as Karl Marx classically noted in the Eighteenth Brumaire of Louis Bonaparte: "Thus Luther donned the mask of the Apostle Paul, the Revolution of 1789 to 1814 draped itself alternately as the Roman republic and the Roman empire, and the Revolution of 1848 knew nothing better to do than to parody, now 1789 , now the revolutionary tradition of 1793 to 1795." ${ }^{3}$ But they could also justify revolutionaries' actions, as each attempt to overthrow tradition contributed to the creation of a new tradition. In this manner, from 1789 to 1989 and beyond, a consciously accumulating revolutionary repertoire came to form the scarlet thread of modernity itself.

In this chapter, I want to suggest that the modern revolutionary script was not entirely original or novel. I will argue instead that it adapted a much older narrative of violent political change. That script also depended on the exercise of

\footnotetext{
${ }^{2}$ François Furet, "The Revolutionary Catechism", in Furet, Interpreting the French Revolution, trans. Elborg Forster (Cambridge, 1981), 83.

${ }^{3}$ Karl Marx, The Eighteenth Brumaire of Louis Bonaparte (1851), in Karl Marx: Selected Writings, ed. David McLellan (Oxford, 1977), 300.
} 
human will. It too featured contestations over sovereignty. And it was likewise shadowed by the spectre of repetition with variation. The palimpsest over which self-conscious revolutionaries wrote their script was a conception of history not as a sequence of revolutions but as a series of civil wars. The earliest version of this script came from republican Rome in the first century BCE but it reached its full flowering between the first and fifth centuries CE. This originally Roman narrative of political violence informed the emerging scripts of revolution in the seventeenth, eighteenth, and nineteenth centuries. Traces of it remain in the twenty-first century, embedded in the assumptions of formal social science and informal political analysis, and in the historiography of modern revolutions. ${ }^{4}$

At first sight, assimilating the modern script of revolution to the ancient script of civil war might seem counter-intuitive, even counter-revolutionary. The two forms of forcible political transformation are usually assumed to be distinct both morphologically and genealogically. According to Reinhart Koselleck, revolution emerged across the course of the eighteenth century "as a concept in contrast to that of civil war." At the beginning of the century, he argued, the two expressions "were not interchangeable, but were not at the same time mutually exclusive." Civil war raised memories of destructive confessional conflict across Europe, the very kinds of events in the past that proponents of Enlightenment hoped to prevent in the future. By contrast, revolution would be the leading edge of positive transformation across all domains of human activity: education, morality, law, politics, and religion. The irrational, atavistic, and destructive activity of civil

\footnotetext{
${ }^{4}$ David Armitage, Civil War: A History in Ideas (New York, 2015).
} 
war would wither away and gradually become impossible. A practical desire to expunge civil war thus gave way to a positive programme for promoting revolution. The result was the final separation of the two concepts by the late eighteenth century. "In many respects", Koselleck concluded, "civil war' had now acquired the meaning of a senseless circling upon itself, with respect to which Revolution sought to open up a new vista." 5

This conceptual opposition between revolution and civil war generated a set of preconceptions, even prejudices, which still endure. Civil wars appear sterile and destructive, while revolutions are fertile with innovation and productive possibility. Civil wars hearken back to ancient grievances and deep-dyed divisions, while revolutions point the way toward an open and expansive future. Civil wars are local, time-bound, and rooted in history while revolutions have occurred across the world in a universal sequence of human liberation. Revolutions mark the unfolding and realization of the emancipated human spirit; civil wars herald only its blighting and collapse. Such contemporary conceptions have their own histories but they should not be projected back onto the past as natural facts and should be understood rather as ideological constructions. As self-conscious revolutionaries from Thomas Paine to V. I. Lenin were well aware, the scripts of civil war and revolution had much in common and were difficult to disentangle. Uncovering some of those commonalities will be the task of the second part of this chapter; firstly, however, we need to

\footnotetext{
${ }^{5}$ Reinhart Koselleck, "Historical Criteria of the Modern Concept of Revolution", in Koselleck, Futures Past: On the Semantics of Historical Time, trans. Keith Tribe (New York, 2004), 46-49; on the conceptual continuities between "revolution" and "civil war", see Neithard Bulst, Jörg Fisch, Reinhart Koselleck, and Christian Meier, "Revolution, Rebellion, Aufruhr, Bürgerkrieg", in Otto Brunner, Werner Conze, and Reinhart Koselleck, eds., Geschichtliche Grundbegriffe. Historisches Lexikon zur politisch-sozialen Sprache in Deutschland, 8 vols. (Stuttgart, 1972-97), V, 653-788, esp. 712-14, 726-27, 778-80
} 
reconstruct the classical script of civil war that later helped to shape modern conceptions of revolution. In light of that reconstruction, the reign of revolution appears to be relatively brief-perhaps two or three centuries at most-while the sequence of civil wars was much longer, stretching back over two thousand years.

The Romans were the first to experience political violence and internal discords as civil wars because they were the first to conceive of them as "civil" even if they were not the first to describe them as "wars". Such upheavals were civil in the sense that they were fought between fellow citizens (cives), within the bounds of a single political community. This distinguished them from staseis, the various forms of sedition and rebellion that divided the Greek polis in which social and political rupture was sometimes understood to be a war (polemos) but where the community was conceived ethnogenetically, even racially, rather than in terms of a common legal or political status as citizens. ${ }^{6}$ As Cicero noted in On Duties, "among the Athenians there were great discords but in our commonwealth there were not only seditions but even accursed civil wars" (pestifera bella civilia). ${ }^{7}$ At least since Cicero himself had first used the term, in 66 BCE, the Romans identified a disturbing and increasing number of their conflicts as fought not against foreigners, allies, pirates, or slaves: these were instead wars by the people of Rome against the people of

\footnotetext{
${ }^{6}$ Nicole Loraux, The Divided City: On Memory and Forgetting in Ancient Athens, trans. Corinne Pache and Jeff Fort (New York, 2002), 107-08, 197-213; Clifford Ando, Law, Language, and Empire in the Roman Tradition (Philadelphia, 2011), 3-4.

${ }^{7}$ Cicero, De officiis, I. 86, in Cicero, On Duties, ed. M. T. Griffin and E. M. Atkins (Cambridge, 1991), 34 (“... apud Atheniensis magnae discordiae, in nostra re publica non solum seditiones sed etiam pestifera bella civilia").
} 
Rome. ${ }^{8}$ Because the standard Roman conception of war defined that condition as both just and directed against an external enemy, the idea of a civil war-bellum civile-was deliberately paradoxical, even oxymoronic. It was nonetheless a distinctively Roman invention.

By general agreement, the first instance of full-blown bellum civile in Roman history had occurred in 88 BCE when the consul Lucius Cornelius Sulla had marched on Rome at the head of his army. Sulla thereby broke the ultimate taboo for any Roman magistrate or commander by breaching the absolute threshold established between the spheres of military and civilian authority, just as Julius Caesar would do still more notoriously four decades later, when he crossed the river Rubicon in 49 BCE. Sulla's opponents, Gaius Marius and P. Sulpicius, confronted him with similar forces inside the bounds of the city itself. At that moment, wrote the Greek-speaking historian Appian in the $2^{\text {nd }}$ century CE, the peculiar elements of civil war could be clearly seen: "there took place a struggle under the guise of civil dissension, but nakedly as a war, complete with trumpets and military standards. ... In this way the episodes of civil strife escalated from rivalry and contentiousness to murder, and from murder to full-scale war; and this was the first army composed of Roman citizens to attack their own country as if it were a hostile power." 9

It may have been the first, but it would be far from the last: over the course of almost a century, from Sulla's march to the succession disputes following the death of the emperor Nero in $69 \mathrm{CE}$, Rome would be wracked by a series of citizens' wars. Trumpets and standards were the visible signs, conventional warfare was the

\footnotetext{
${ }^{8}$ Cicero, De imperio Cn. Pompei, 28, in Cicero, Political Speeches, trans. D. H. Berry (Oxford, 2006), 119.

${ }^{9}$ Appian, The Civil Wars (I. 59-60), trans. John Carter (Harmondsworth, 1996) 32-33.
} 
means, and control of the city of Rome was the aim: all told, these were the identifying marks of the script of civil war rather than signs of mere tumult, dissension, or sedition. Tumults and seditions-like later conceptions of rebellion or revolt, for instance-implied to the Romans episodic and non-recurrent expressions of political violence. Civil wars, by contrast, increasingly came to appear sequential and cumulative across the course of Roman history. Sulla's first war against Marius in 88-87 BCE led to a second in 82-81 BCE. Catiline's conspiracy was quashed before Caesar had brought his army from Gaul to confront Pompey. That led in turn to the cycle of intermittent and transnational violence that spanned the Mediterranean (and beyond) in the years from 49-31 BCE. In these decades, it became increasingly easy to believe that Rome was cursed by civil war, and that it was doomed to reiterate citizens' conflicts cumulatively and endlessly in a deadly and debilitating series. $^{10}$

After the death of Augustus, the cycle of civil war-and the sequence of civil war writing-remained unbroken. Of making books about civil war, there would be no end. The greatest surviving treatments of Rome's civil wars were written between the 60s and the 160s AD: most notable were Lucan's epic poem, the Bellum Civile (60-65), Tacitus's Histories (c. 109), Plutarch's Roman lives of the Gracchi, Marius, Sulla, Caesar, Pompey and Antony (c. 100-25), Florus's Epitome (c. 117-38 or 161-69), and the surviving books of Appian's Roman History treating the Civil Wars (c. 145-65). Tacitus covered the wars of succession that followed the death of

\footnotetext{
${ }^{10}$ Paul Jal, La guerre civile à Rome. Étude littéraire et morale (Paris, 1963); John Henderson, Fighting for Rome: Poets and Caesars, History and Civil War (Cambridge, 1998); Brian Breed, Cynthia Damon, and Andreola Rossi, eds., Citizens of Discord: Rome and its Civil Wars (Oxford, 2010).
} 
the emperor Nero, in the so-called Year of the Four Emperors (69), which he opened with a warning: "I am entering on a work full of disasters, terrible in its battles, riven by seditions, in which even peace was savage. Four emperors were cut down by the sword; there were three civil wars, more foreign wars and many that were mixed" (trina bella civilia, plura externa, ac plerumque permixta). ${ }^{11}$ Florus's Epitome told Rome's history in the seven centuries from Romulus to Augustus as a sequence of wars, foreign, servile, social, and civil. And Appian made his comprehensive attempt to encompass all Rome's civil wars from Sulla to Octavian in the surviving books of his Roman History. Their accounts formed the matter of Rome's civil wars into sequences both genealogical and teleological that probed Romans' moral failings, diagnosed civil war as the city's seemingly unshakeable curse, and prescribed remedies for the disease or condemned its victims.

Civil wars appeared to be successive and cumulative across the course of Roman history. They came not singly but in battalions, and left wounds that would not heal, heirs who demanded vengeance, and divisions that split first the city itself and then the entire Roman Empire in the Mediterranean and beyond. These were unforgettable traumas, seared in the memory and likely to recur at any time. A grieving parent who had lived through Sulla and Marius's civil wars and then suffered through Caesar and Pompey's contentions forty years later lamented this cycle in Lucan's poem, The Civil War: "These sufferings await, again to be endured, this will be the sequence/ of the warfare, this will be the outcome fixed for civil

11 Tacitus, Historiae (I. 2), in Tacitus, Histories, Books I-III, trans. Clifford H. Moore (Cambridge, Mass., 1925), 5 . 
strife." 12 This was a sequence that looked like it might become a cycle, a repetitious and destructive series of events that closely tracked and decisively informed the pivotal moments in Roman politics.

The Roman narratives of civil war took three broad forms, each of which would inform later understandings of internal violence in the West and help variously to inspire both revolutionary ideologies and counterrevolutionary ideologues. First, there was what might be called the republican narrative of seemingly endless and repeated civil wars arising from the very fabric of Roman civilisation itself: to be civilised at all was to be prone to civil war, and to suffer one civil war opened the way for further destructive dissensions within the commonwealth: "'Tis in vain to seek a Government in all points free from a possibility of Civil Wars, Tumults, and Seditions", warned the aristocratic English republican, Algernon Sidney, in the early 1680s: "that is a Blessing denied to this life, and reserved to compleat the Felicity of the next".13 Then there was a parallel imperial or Augustan narrative, which followed much the same pattern but held that the only cure for the pathology of civil war would be the restoration of monarchy or the exaltation of an emperor. "In this way", wrote Appian, "the Roman polity survived all kinds of civil disturbances to reach unity and monarchy": "an evident demonstration", agreed his late sixteenth-century English translator, "That peoples rule must give place, and Princes power prevayle." ${ }^{14}$ And finally there was a Christian narrative, constructed most famously by Augustine, which presented

\footnotetext{
${ }^{12}$ Lucan, Bellum civile (2, 223-34), in Lucan, Civil War, trans. Susan H. Braund (Oxford, 1992), 27.

${ }_{13}^{13}$ Algernon Sidney, Discourses Concerning Government (London, 1698), 172.

${ }^{14}$ Appian, The Civil Wars, trans, Carter, 4 (I. 6); [Appian,] An Auncient Historie and exquisite Chronicle of the Romane warres, both Civile and Foren (London, 1578), title-page.
} 
Rome's pagan history as a catalogue of "those evils which were more infernal because internal" (quanto interiora, tanto miseriora), a series of "civil, or rather uncivil, discords" (discordiae civiles vel potius inciviles). "How much Roman blood was shed, and how much of Italy destroyed and devastated", Augustine lamented, "by the Social War, Servile Wars and Civil Wars!" (bella socialia, bella servilia, bella civilia). The contrast with that peaceable civitas, the City of God, could hardly have been greater..$^{15}$

These narratives of civil war would not, and could not, be forgotten as long as the Roman historians and poets continued to be read and imitated. There has been much debate among historians whether books made revolutions in the early modern period, but there can be little doubt that civil conflicts were good for book sales. The reputations of Roman writers on civil war closely tracked the prevalence of civil conflict. Between 1450 and 1700, Roman historians greatly outnumbered their Greek predecessors in the number of editions of their works: five of the top ten were histories of civil war or by historians of civil war, as Sallust's Catiline and Jugurtha were the two most frequently printed texts, with Caesar, Tacitus, and Florus, who portrayed the seven centuries from Romulus to Augustus as a sequence of wars, not far behind. Florus became a mainstay of early modern school and university curricula: editions of his Epitome appeared almost annually across Europe during the eighteenth century. Through his text and that of his fellow epitomist, the $4^{\text {th }}$-century historian Eutropius, many canonical thinkers derived their first immersion in Roman history from Florus: Hobbes knew his work well-it

\footnotetext{
${ }^{15}$ Augustine, The City of God against the Pagans, ed. R. W. Dyson (Cambridge, 1998), 132, 929 (III. 23; XIX. 7).
} 
partly inspired his "Epitome" of the English Civil Wars, Behemoth (1679)—and Locke would have read him at Oxford, as Adam Smith later studied Eutropius. ${ }^{16}$

Such synoptic and serial accounts of Rome's civil wars inspired the genre of European historical writing that presented the histories of particular nations or peoples as a narrative of their "revolutions"-meaning their external invasions, succession disputes, and civil wars. Late seventeenth- and early eighteenth-century historians such as Laurence Echard, in The Roman History from the Building of the City to the Perfect Settlement of the Empire by Augustus Cæsar (1695, and later editions), and the abbé René Aubert de Vertot, in his Histoire des révolutions arrivées dans le gouvernment de la république romaine (1719, and later editions), represented Roman history as a sequence of disruptive "revolutions" by which Rome had moved over the centuries from monarchy to empire via the Republic. Vertot capitalized on the success of his Roman revolutionary history with sequels on the histories of revolutions in Portugal and Sweden, and his imitators anatomized revolutions throughout European history and in the wider Eurasian world. ${ }^{17}$ Throughout the life-span of this genre, civil wars were included among the roster of revolutions and revolutions could not be distinguished conceptually from civil wars. "Revolutions" also became the standard European description for violent upheavals

\footnotetext{
${ }^{16}$ Peter Burke, "A Survey of the Popularity of Ancient Historians, 1450-1700", History and Theory 5 (1966), 135-52; Paul Seaward, "Clarendon, Tacitism, and the Civil Wars of Europe", Huntington Library Quarterly 68 (2005), 289-311; Freyja Cox Jensen, "Reading Florus in Early Modern England", Renaissance Studies 23 (2009), 659-77; Jensen, Reading the Roman Republic in Early Modern England (Leiden, 2012), 56-73; Thomas Hobbes, Behemoth, ed. Paul Seaward (Oxford, 2010), 52; Statutes of the University of Oxford Codified in the Year 1636 under the Authority of Archbishop Laud, ed. John Griffiths (Oxford, 1888), 37; Nicholas Phillipson, Adam Smith: An Enlightened Life (London, 2010), 18.

${ }_{17}$ Arnaldo Momigliano, "Ancient History and the Antiquarian", Journal of the Warburg and Courtauld Institutes 13 (1950): 294; Jean Marie Goulemot, Le règne de l'histoire. Discours historiques et révolutions XVII ${ }^{e}$-XVIII ${ }^{e}$ siècles (Paris, 1996), 127-56.
} 
in Asia, such as the fall of the Ming dynasty in China in 1644. Only towards the end of the eighteenth century did Europeans cease to call these Asian struggles "revolutions", as they reserved that term for their own political transformations. ${ }^{18}$

Most of these histories of revolutions served absolutist purposes by showing the advantages of monarchy over other regimes. ${ }^{19}$ But the republican narrative of civil war also survived to provide a counterpoint to the broadly Augustan account of the unsettling effects of revolutions. In this version of events, monarchy was not the cure for political instability: it was its cause. And civil war, like other manifestations of revolution, might therefore be welcomed as a purge rather than feared as a scourge. As the Commonwealthman noted in the abbé de Mably's Des droits et des devoirs du citoyen (1758), the oppressors of society have a magical ability to persuade their citizens not to disturb the progress of their usurpations and injustices, "and that civil war, for a people still virtuous enough to profit from it, is nonetheless a greater scourge than the tyranny which threatens it." It was the duty of a people-in this case, the French people-to resist such mystifications about both tyranny and civil war and to follow instead the path of constitutional reform and political resistance. Mably's "script for a French revolution" therefore sprang from the Roman tradition of narrating history as a sequence of civil wars. And it did so in dialogue with a British version of that narrative whose roots lay in the Exclusion Crisis of the late seventeenth century. Both would come to inform an early

\footnotetext{
18 Sven Trakulhun, "Das Ende der Ming-Dynastie in China (1644). Europäische Perspektiven auf eine 'große Revolution'”, in Sven Grampp, Kay Kirchmann, Marcus Sandl, Rudolf Schlögl, and Eva Wiebe, eds., Revolutionsmedien-Medienrevolutionen (Konstanz, 2008), 475-508.

${ }^{19}$ Baker, "Inventing the French Revolution", in Baker, Inventing the French Revolution, 207-09.
} 
version of the so-called "democratic peace" argument in the late eighteenth century age of revolutions—and civil wars..$^{20}$

The transformation of the ancient story of civil war into a modern script for revolution began with the staunchly monarchist writing of Sir Robert Filmer and proceeded via Algernon Sidney's equally vehement republican refutation of Filmer to the work of the abbé Mably, Thomas Paine, and Edmund Burke. In order "to manifest the Imperfection of Popular Government", Filmer in his Patriarcha (c. 1628; pub. 1680) had portrayed Rome's "Democratie" as turbulent and short-lived: a mere 480 years, from the expulsion of Rome's last king, Tarquinius Superbus, to the rise of Julius Caesar. Conflict between the nobility and people led to seditions; these seditions then spawned a destructive sequence of civil wars: "the Social War was plainly Civil; the Wars of the Slaves, and the other of the Fencers; the Civil Wars of Marius and Sylla, of Cataline, of Caesar and Pompey the Triumvirate, of Augustus, Lepidus and Antonius: All these shed an Ocean of Blood within Italy and the Streets of Rome." These wars continued even while Rome expanded, as its citizens turned their conquering arms upon themselves, until the "Civil Contentions at last settled the Government again into a Monarchy." To prove the necessity of monarchy and the instability of "Democratical Government", Filmer turned the republican

\footnotetext{
${ }^{20}$ Gabriel Bonnot de Mably, Des Droits et des devoirs du citoyen, ed. Jean-Louis Lecercle (Paris, 1972), 66 (my translation); Keith Michael Baker, "A Script for a French Revolution: The Political Consciousness of the abbé Mably", in Baker, Inventing the French Revolution, 94.
} 
narrative of civil war on its head in the service of an Augustan account of the benefits of monarchy for securing peace..$^{21}$

Algernon Sidney returned to the Roman republican narrative of civil warand in particular to Sallust's version of it-to refute Filmer's defence of patriarchal monarchy. He argued that it was not adherence to a republican constitution that had caused Rome's seditions and ultimately its civil wars: it was straying from that constitution and allowing the spoils of empire to foster inequality and to corrupt private life. Sidney also took Filmer to task for his overexpansive application of the term civil war: "tis most absurdly applied to the servile and gladiatorian Wars; for the Gladiators were Slaves also, and Civil Wars can be made only by those who are Members of the Civil Society, which Slaves are not. Those that made the bellum Sociale, were Freemen, but not Citizens; and the War they made could not be called Civil." When Caesar and Pompey, the members of the triumvirate, and the four emperors who followed Augustus engaged in what were rightly called "civil" wars, their armed contentions could not be used to discredit popular government. The civil conflicts of the republican era were "the last Struglings of expiring Liberty", while those under the empire, and "all the Mischiefs that accompanied them, are to be imputed wholly to the Monarchy for which they [Nero, Galba, Otho, Vitellius, and Vespasian] contended."22

This difference between republican and monarchical government was universal in the Latin West not simply a contingent feature of Roman politics. Sidney argued that "All monarchies are subject to be afflicted with civil wars ... But

${ }^{21}$ Sir Robert Filmer, Patriarcha: Or the Natural Power of Kings (London, 1680), 54, 55-56, 58.

${ }^{22}$ Sidney, Discourses Concerning Government, 121. 
commonwealths are less troubled with those distempers": indeed, as the title of his chapter on the subject had it, "Popular Governments are less subject to Civil Disorders than Monarchies; manage them more ably, and more easily recover out of them." This was in large part because non-monarchical regimes did not suffer from the destructive disputes over inheritance and the succession that bedevilled monarchies. Sidney showed this distinction by a detailed breakdown of all the violent disturbances across history: in Israel under its kings, in the Persian monarchy, in Rome, France, Spain, and Britain. For example, the succession caused "many Revolutions" in France where, as in Rome, "the end of one Civil War has bin the beginning of another." As if the pages of evidence from the Mediterranean and northern Europe were not enough to convince his readers, Sidney concluded with the litany of civil wars that had scarred England since the Norman Conquest: "the Miseries of England on like occasions", he wrote, "surpass all". From the contested succession after the death of William the Conqueror to the troubles of the Tudors, English history appeared to be an almost continuous time of troubles for five centuries. ${ }^{23}$ What more could be needed to show that it was monarchy that bred war, and republicanism that brought peace, in the ancient world as in the modern?

The most incendiary use of this argument was Thomas Paine's in Common Sense (1776). Writing in Philadelphia in January 1776, Paine sought to shake his colonial readers out of their complacent British monarchism by linking a plea for republican government with his larger argument in favour of independence from Great Britain. He contrasted his own attachment to republicanism with what he

${ }^{23}$ Sidney, Discourses Concerning Government, 187-89, 193, 196-99. 
called the "most plausible plea, which hath ever been offered in favour of hereditary succession", in a passage that hewed closely to Sidney's arguments from almost a century earlier, not least by recalling the claims of Filmerian patriarchalists. Their justification for monarchy was

that it preserves a Nation from civil wars; and were this true, it would be weighty; whereas, it is the most barefaced falsity ever imposed upon mankind. The whole history of England disowns the fact. Thirty kings and two minors have reigned in that distracted kingdom since the conquest, in which time there have been (including the [Glorious] Revolution) no less than eight civil wars and nineteen Rebellions. Wherefore instead of making for peace, it makes against it, and destroys the very foundation it seems to stand on. ... In short, monarchy and succession have laid (not this or that kingdom only) but the world in blood and ashes. ${ }^{24}$

Paine went beyond Sidney—who had been executed in 1683—by adding the Glorious Revolution to the list of England's troubles, and by inference to its roster of civil wars. $1688-89$ was a year of two kings, and thereby no doubt only half as bad as the year of the four emperors chronicled by Tacitus in his Histories. Far from being the upheaval that secured the recovery of England's "civil and political liberties" (as Sir William Blackstone had described it), the Glorious Revolution was simply one more example of how a contested succession could lead to national instability, setting citizens against citizens in their quest to affirm their monarchical subjecthood. ${ }^{25}$ Most wrenchingly of all, it was part of a narrative of successive civil wars like that traced by Tacitus and other Roman historians. Yet the cure for civil war was not, as the pro-Augustan writers and their heirs asserted, the imposition of monarchy. It was instead what Sidney and his readers, like the Commonwealthman

\footnotetext{
${ }^{24}$ Thomas Paine, Common Sense (1776), in Paine, Collected Writings, ed. Eric Foner (New York, 1995), 18-19.

${ }^{25}$ Sir William Blackstone, Commentaries on the Laws of England, 4 vols. (Oxford, 1765-69), IV, 435.
} 
in Mably's Des droits et des devoirs du citoyen, had recommended: namely, popular government rather than hereditary succession.

Paine would not be alone in identifying the Glorious Revolution as a civil war. Writing almost fifteen years after him in 1790, Edmund Burke noted acidly that the "ceremony of cashiering kings"

... can rarely, if ever, be performed without force. It then becomes a case of war, and not of constitution. Laws are commanded to hold their tongues against arms, and tribunals fall to the ground with the peace they are no longer able to uphold. The Revolution of 1688 was obtained by a just war, in the only case in which any war, and much more a civil war, can be just. Justa bella quibus necessaria. ${ }^{26}$

Why did these events constitute a "civil" war? Possibly Burke wrote here as an Irishman rather than an English politician by recalling the conflict between James II and William III on his native soil and its enduring consequences for Ireland. In this light, the Glorious Revolution was "not a revolution, but a conquest; which is not to say a great deal in its favour". ${ }^{27}$ Or Burke may have remembered the English side of the Revolution as an invasion by one claimant to the thrones of the Three Kingdoms, backed by force and his English supporters, against another. Either way, he made an essentially Lockean argument for the exceptionality of what had happened in 1688. Dethroning a monarch could not be regulated by law or determined by right: it was a question of armed necessity and hence of war. And because it was fought between members of the same polity, it was by definition civil.

\footnotetext{
${ }^{26}$ Edmund Burke, Reflections on the Revolution in France (1790), ed. J. G. A. Pocock (Indianapolis, 1987), 26-27 (quoting Livy, Histories, 9.1.10) (my emphasis).

${ }^{27}$ Edmund Burke, A Letter from the Right Hon. Edmund Burke ... to Sir Hercules Langrishe ... on the Subject of Roman Catholics of Ireland (London, 1792), 41. My thanks to Richard Bourke for this reference.
} 
Paine and Burke saw the events of $1688-89$ as both a revolution-indeed, as the Revolution, the only one up to that point in British and Irish history-and a civil war: a just war, in Burke's case, an unjust war in Paine's. If Paine had been right in 1776, then the Glorious Revolution was the culmination of a series of unsettling contentions over the succession, with 1688 as a year of two kings to parallel the year of the four Emperors chronicled by Tacitus in his Histories. Yet if Burke was correct in 1790, then the Glorious Revolution was an unrepeatable exception, an extreme example of necessity, and not the inevitable recurrence of an inescapable sequence: it was a civil war that transcended the repetitive compulsions predicted by Roman narratives. Despite these fundamental differences, Paine and Burke's identifications of the Glorious Revolution as a civil war give the lie to Koselleck's argument that revolution and civil war had separated semantically and conceptually by the end of the eighteenth century. Even in the Age of Revolutions they were not mutually exclusive, even if not entirely interchangeable.

And so, indeed, they remained long after the late eighteenth century.28 Revolutionaries redescribed what in other circumstances-or by other ideologueshad been called rebellions, insurrections or civil wars. Indeed, one sure sign of a revolution's success is precisely that retrospective redescription. The renaming can happen relatively quickly: for example, the transatlantic conflict of the 1770 s that many contemporaries saw as a British "civil war" or even "the American Civil War" was first called "the American Revolution" in 1776 by the chief justice of South

\footnotetext{
${ }^{28}$ Compare Pier Paolo Portinaro, "Introduzione: Preliminari ad una teoria della guerra civile", in Roman Schnur, Rivoluzione e guerra civile, ed. Portinaro (Milan, 1986), 3-49; Paolo Viola, "Rivoluzione e guerra civile", in Gabriele Ranzato, ed., Guerre fratricide. Le guerre civili in età contemporanea (Turin, 1994), 526.
} 
Carolina, William Henry Drayton. ${ }^{29}$ The rebranding can also come more slowly, as when the French historian François Guizot became among the first in 1826 to call the mid-seventeenth-century crisis in Britain the "English Revolution", on the grounds that "the analogy of the two revolutions is such that [the English] would never have been understood had not [the French] taken place." ${ }^{30}$ As the English poet Sir John Harington might have put it in one of his late sixteenth-century epigrams:

Civil war doth never prosper: what's the solution?

For if it prosper, it's called revolution. ${ }^{31}$

To recover the modern script of revolution, we need to be alert to the scripts of civil war revolutionaries followed and subsequently attempted to efface or deny. Inspiration for this task comes from some of the greatest theorists of revolution themselves. In The Communist Manifesto, Marx and Engels noted that, "[i]n depicting the most general phases of the development of the proletariat, we traced the more or less veiled civil war [den mehr oder minder versteckten Bürgerkrieg], raging within existing society, up to the point where that war breaks out into open revolution." ${ }^{2}$ Similarly, Lenin argued in 1917 that "civil wars ... in every class society are the natural, and under certain conditions, inevitable continuation, development and intensification of the class struggle. That has been confirmed by

${ }^{29}$ Civil War; a Poem. Written in the Year 1775 [n.p., n.d. (1776?)], sig. A2r; David Hartley, Substance of a Speech in Parliament, upon the State of the Nation and the Present Civil War with America (London, 1776), 19; John Roebuck, An Enquiry, whether the Guilt of the Present Civil War in America, Ought to be Imputed to Great Britain or America [n. p., n.d. (1776?)]; William Henry Drayton, A Charge, on the Rise of the American Empire (Charlestown, SC, 1776), 2, 8, 15.

${ }^{30}$ François Guizot, Histoire de la révolution d'Angleterre (1826), quoted in J. C. D. Clark, Rebellion and Revolution: State and Society in England in the Seventeenth and Eighteenth Centuries (Cambridge, 1986), 37.

${ }^{31}$ The original epigram runs: "Treason doth neuer prosper? What's the Reason?/ for if it prosper none dare call it treason": Sir John Harington, Epigrams, III. 43, in The Epigrams of Sir John Harington, ed. Gerard Kilroy (Farnham, 2009), 185.

${ }^{32}$ Karl Marx and Friedrich Engels, The Communist Manifesto (1848), in Karl Marx: Selected Writings, ed. McLellan, 230. 
every great revolution." ${ }^{33}$ Looking back on the Russian Revolution a decade later, Stalin agreed: "the seizure of power by the proletariat in 1917 was a form of civil war." 34 There is now considerable evidence in the literature on revolutions that civil war was an actors' category, as well as a revealing analytical optic for evaluating the causes, course and consequences of such events as the American, French, and Spanish American "revolutions" ${ }^{35}$ In light of this, when tracing the genealogy of the modern script of revolution, we should seriously consider the hypothesis that civil war was the original genus of which revolution was only a late-evolving species. ${ }^{36}$

${ }^{33}$ V. I. Lenin, The Military Programme of the Proletarian Revolution (September 1916), in Lenin, Collected Works, 45 vols. (Moscow, 1960-70), XXIII, 78.

${ }^{34}$ Josef Stalin (1928), quoted in Alfred J. Rieber, "Civil Wars in the Soviet Union”, Kritika 4 (2003), 140.

${ }^{35}$ See, for example, Wim Klooster, Revolutions in the Atlantic World: A Comparative History (New York, 2009), 11-44; Maya Jasanoff, Liberty's Exiles: American Loyalists in the Revolutionary World (New York, 2011), 21-53; Alan Taylor, The Civil War of 1812: American Citizens, British Subjects, Irish Rebels, and Indian Allies (New York, 2010); Jean-Clément Martin, La Vendée et la Révolution (Paris, 2007); David Andress, The Terror: Civil War in the French Revolution (London, 2005); Manuel Lucena Giraldo, Naciones de rebeldes. Las revoluciones de independencia latinoamericanas (Madrid, 2010); Tomás Pérez Vejo, Elegía criolla. Una reinterpretación de las guerras de independencia hispanoamericanas (México, D.F., 2010).

${ }^{36}$ Pace Pierre Serna, "Toute révolution est guerre d'independance", in Jean-Luc Chappey, Bernard Gainot, Guillaume Mazeau, Frédéric Régent, and Pierre Serna, Pour quoi faire la Révolution (Marseille, 2012), 1949; Serna, "Every Revolution is a War of Independence", in Suzanne Desan, Lynn Hunt, and William Max Nelson, eds., The French Revolution in Global Context (Ithaca, NY, 2013), 165-82. 
David Armitage is the Lloyd C. Blankfein Professor of History at Harvard University, where he teaches intellectual history and international history. Among his fourteen books to date are, as author, The Declaration of Independence: A Global History (2007), and Foundations of Modern International Thought (2013), as coauthor, The History Manifesto (2014), and, as co-editor, The Age of Revolutions in Global Context, c. 1760-1840 (2010) and Pacific Histories: Ocean, Land, People (2014). 